\title{
DEVELOPING INSTRUCTIONAL MATERIALS BASED ON INQUIRY LEARNING MODEL
}

\author{
Nur Fadilasari \\ Universitas Islam Negeri Alauddin Makassar \\ nurfadilasari83@gmail.com \\ Djuwairiah Ahmad \\ Universitas Islam Negeri Alauddin Makassar \\ Djuwairiah.ahmad@uin-alauddin.ac.id \\ Sitti Nurpahmi \\ Universitas Islam Negeri Alauddin Makassar \\ Sitti.nurpahmi@uin-alauddin.ac.id
}

DOI: https://doi.org/10.24252/elties.v2i1.11275

\begin{abstract}
This research aimed at developing instructional English materials for the students of the seventh grade especially in basic competencies 3.1, 4.1, 3.2, and 4.2 at MTs Madani Pao-pao based on 2013 curriculum supported by using inquiry learning model and the concept of HOTS in indicators achieved. The research design used in this study was Research and Development (R\&D). The development model used was ADDIE model. It consists of need analysis, design, development, implementation, and evaluation. The procedures included analyzing materials needed by spreading questionnaire to the students and analyzing the basic competencies used, designing a blueprint of materials and the instructional materials, and validating the material by the expert. There were 146 students as the respondents of 26 questionnaire questions. The instruments used in this research were the documents, questionnaire, and validation checklist. In this research, the expert was involved in order to validate the product. There were three systematic aspects that were validated: Materials Systematic Organization, Systematic English Teaching and Systematic Content of English. Therefore, the result indicated that based on experts judgment as well as product development result, the developed basic competency $3.1 \& 4.1$ and basic competency $3.2 \& 4.2$ were applicable to be taught at the seventh grade students of Junior High School as topic in English for them.
\end{abstract}

Keywords: English instructional materials, inquiry learning model, HOTS

\section{INTRODUCTION}

The product of the 2013 curriculum is a book which is compiled by the government that contains the material which taught to the students by the teachers, then disseminated throughout Indonesia so that the quality distribution of education can be the same in all regions of Indonesia. Material 


\section{Volume 2, Number 1, March 2020}

is an important part of the teaching and learning process. Many researches offer instructional materials developed for teaching. Therefore, the researcher wants to produce a work in the form of a book in order to facilitate the transfer of knowledge from teacher to student.

Garinger (2002) points out, as the main English instructional material, English textbook in English as foreign language (EFL) are very important roles to facilitate language acquisition in the classroom. An English textbook entitled "Bahasa Inggris: When English Rings the Bell” is a new English textbook prepared by the Ministry of Education and Culture of Indonesia (MECI) in line with the implementation of new designed curriculum, 2013 curriculum. This book is distributed for free to all schools in Indonesia that have already applied 2013 curriculum and also available in the website of Ministry of Education and Culture for free download. Additionally, all schools in Indonesia have started to implement the 2013 curriculum in the new academic year (2014/2015) so this book is used by all junior high school in Indonesia. Because of these facts, the use of this English textbook is automatically widespread, so that the English teachers need to see inside the materials on textbook in order to take more control over its use.

Based on the explanation above, the book that already exist is currently used by some schools that implement K-13 which is compiled based on the scientific approach without any learning model that follows it. As for the scientific approach that underlies this book, it has been well developed and has been implemented in Indonesia, but it would be better if there is learning model that followed this book so that teachers will be easier to deliver the materials. This is accordance to Suprijono (2011: 46) textbook that is equipped with a learning model through teacher learning strategies can help students get information, ideas, skills, ways of thinking and expressing ideas. The learning model functions as a guide for learning designers and teachers in planning teaching and learning activities. Based on the statement, the researcher will develop the textbook which has not only an approach but also a learning model.

The curriculum is an educational instrument to be able to make Indonesian students have competencies in attitudes, knowledge and skills so that they can be productive, creative, innovative and affective individuals and citizens. If it is associated with the concept of education, then the objectives of the curriculum for students themselves can be represented through HOTS (Higher Order Thinking Skill) concept. According to Lorin Anderson and David Krathwohl (2001), the level of thinking ability starts from (1) remembering; (2) understanding; (3) applying; (4) analyzing; (5) evaluating up to (6) creating. Levels of thinking ability (1), (2), and (3) are 
categorized as Lower Order Thinking Skills (LOTS) or low-level thinking abilities. While the level of thinking ability (4), (5), and (6) are categorized as HOTS or high-level thinking skills. The explanation above is a consideration for researcher to apply the concept of HOTS to the 2013 curriculum through an inquiry learning model.

Various researches had conducted a research related to English material about developing material. Djuwairiah Ahmad (2014) found that the application of K-13 in ELT is partial, biased, and tends to be traditional from planning for the assessment process and also the obstacles are rooted in the mindset of the teachers and its implementation. Next, Miftahul Khair Nur Ali Mubar (2015) revealed that designed English speaking material for students to be able to accommodate students' needs in learning speaking related to students' daily activity that can improve student speaking ability. In addition, Ilmiah \& Nur (2018) revealed that that eight grade students preferred English instructional materials accompanied by pictures and examples relating to the daily lives of students. Finally, Gary Nottis at. al. (2018) investigated the impact of inquiry learning activities on students' conceptual understanding of four critical heat transfer concepts and result of the study indicated that the understanding of students' concepts in general has increased which lead the students to be able to solve problems with the same concept.

Based on the condition and explanation above, the researcher expected that this research can solve the problems stated previously by developing instructional materials, especially in English for the seventh grade of junior high school based on the inquiry learning model.

\section{Developing Material}

The developing material is a step taken in improving the quality of the learning process, such as in terms of concept, material, method, or method of application. The basic principle of developing English instructional materials according to Tomlinson (2012) who presented the basic principles those are relevant to the development of material. The English instructional materials that are prepared should be has a positive impact that can be learned, make the students feel comfortable to develop their confidence in the learning process, using language features that can attract students' attention which can facilitate their understanding, not forgetting that there are

differences in learning styles of each student, consider the possibility of occurrence of a period of silence (students may not be forced to speak) at the beginning of the learning period, and maximizing various potentials of students by involving intellectual, aesthetic, and emotional intelligence. 
Volume 2, Number 1, March 2020

\section{The Concept of the 2013 Curriculum}

On July 2013, the Education and Cultural Ministry of Indonesia established the 2013 curriculum as an initiative better for the previous curriculum. Mulyasa (2013:65) said that the 2013 curriculum had the crucial objective to encourage the learners' ability to conduct observing, asking, reasoning, and communicating or presenting of what they learned or they knew after receiving subject matter. In Modul Pelatihan Implementasi Kurikulum (2014:4), the 2013 curriculum was the development of curriculum with base competence from the previous curriculum in KBK 2004 and KTSP 2006 which had attitude, knowledge, and skill. There were four competences for the 2013 curriculum; Kompetensi inti-1 (KI-1) for religious competence; Kompetensi inti-2 (KI-2) for social competence; Kompetensi inti-3 (KI-3) for cognitive competence; Kompetensi inti-4 (KI-4) for skill competence.

\section{The Concept of HOTS (High Order Thinking Skill)}

HOTS (High Order Thinking Skills) was originally known from the concept of Benjamin S. Bloom which categorizes various levels of thought called Bloom Taxonomy, from the lowest to the highest. HOTS itself is part of the cognitive realm in Bloom's Taxonomy and aims to hone mental skills around knowledge. The cognitive version of the Bloom version was later revised by Lorin Anderson, David Karthwohl, et al. (2001). The order was changed to six, namely: Remembering; Understanding; Applying; Analyzing; Evaluating; and creating. Levels 1 to 3 are categorized as low-order thinking skills (LOTS), while levels 4 to 6 are categorized as high-order thinking skills (HOTS).

\section{Inquiry Learning}

Inquiry learning model was pioneered by John Dewey, who was a former science teacher. Educational Development Center (2016) states that Inquiry learning is a teaching method that provides opportunity for students to find out their own knowledge that they don't know. Dewey then encouraged the science instructor to use the inquiry at K-13 which at that time the steps were still stiff. There are 6 steps, namely sensing perplexing situations, clarifying the problem, formulating a tentative hypothesis, testing the hypothesis, revising with rigorous tests, and acting on the solution.

Based on the inquiry model, schools play the best role to facilitate self-development. Therefore, inquiry is centered on students, so that students participate actively in the learning process. The learning process is seen as an important outcome such as the product, for example 
what is learned. While the teacher in the Inquiry Learning model acts as a facilitator who presents challenges to students by helping them identify questions and problems, and guide the course of inquiry learning. Thus, the inquiry approach views students as thinkers who actively seek, examine, process data from their environment towards a variety of objectives that best suit their mental characteristics (Heru Kusmaryono, 2013).

\section{METHOD}

The research design used by researcher was Research and Development (R\&D). The researcher adopts ADDIE Model. ADDIE stands for Analyze, Design, Develop, Implement, and Evaluate was designed to ensure that the learners achieved the goals and objectives of the learning purposes. It also provided simple procedure to design and develop materials. In addition, it was an iterative evaluation of each phase might lead the instructional designer back to any previous phase. The scheme of the steps of the ADDIE design model in this study is shown in figure 1 below:

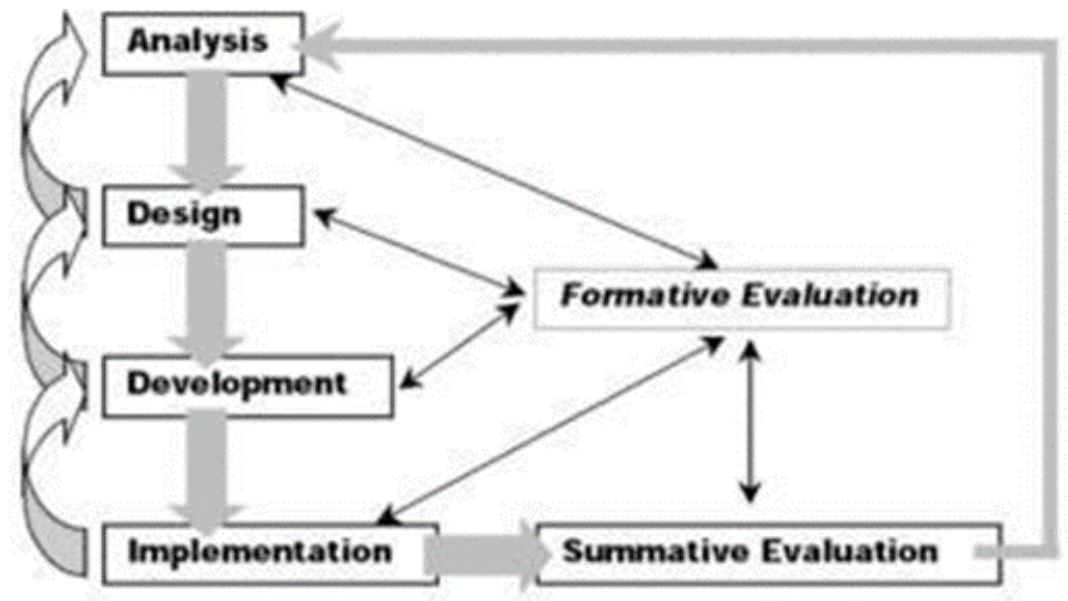

Figure 1. The ADDIE's Model (McGriff, 2000)

The types of data in this research were qualitative and quantitative data. The qualitative data was gathered from the analyzing basic competence of $3.1 \& 4.1$ and $3.2 \& 4.2$ of the Permendikbud Number 24 year 2016 in appendix 37. The quantitative data were obtained from the result of questioners and the validation of the expert in evaluating product that has been made by researcher, whether they were feasible or not feasible to be used as references by students, teachers and the government to be used in the learning process.

In this research, three instruments were used. The first was documents containing the syllabus of 2013 curriculum revised edition which was published in 2017 by the government, basic 
Volume 2, Number 1, March 2020

competence analysis, and the blueprint of materials. The second was questionnaire adapted by Andi Kaharuddin (2015: p.75-78) for the students. The third was the validation checklist adapted from Ghobrani (2011: p.517-520) and Widyatmoko (2011) cited by Sukirman (2013) and filled out by the experts.

The technique followed several steps by Miles and Huberman. They suggest that in analyzing the data qualitatively consists of three procedures. The first was data reduction, the second was data display and the third was conclusion draw. In gathering information from students and experts the researcher used the need analysis questionnaires and validation checklist. Types of questions are linguistic needs and learning needs used for assessing whole needs of the target. Because of the subject of this research was the first grade of junior high school, so the researcher used yes/no question in getting students' needs.

\section{FINDING AND DISCUSSION}

\section{The Process of Developing English Material for the Seventh Grade of Junior High School Based on Inquiry Learning Model by Using ADDIE Model}

In making decision about the needs analysis phase, the researcher determined the type of information needed, the participant to be investigated, and the instrument used. The information needed through the stage of need analysis include to find out the learning styles of students, the experience of students in learning English in class VII, and the learning media that students like. There were two participants involved, namely 146 students from MTs Madani Paop-Pao at the seventh grade of 2018-2019 school year who were studying the materials and people working in the teaching department. The instrument used to carry out this stage was a questionnaire containing several questions related to information previously explained and a questionnaire as a benchmark for validate the instructional materials that had been designed. After that, researcher gathered information through two ways, namely analysis of students' needs and analysis of basic competencies.

The questionnaire was formulated by yes/no question, so the students only need to choose yes or no in every question. After analyzing the questionnaire, the researcher informed the result by the tables below:

Table 1 . The overall needs inventory from linguistic needs

\begin{tabular}{lll}
\hline \multicolumn{2}{c}{ The learning abilities } & \multicolumn{1}{c}{ The learning priorities } \\
\hline - Can introduce their self by using English $\quad-\quad \begin{array}{l}\text { The students like learning English } \\
\text { subject }\end{array}$ \\
\hline
\end{tabular}


- Cannot write their daily activity by using English

- Cannot read an English short story fluently
- $\quad$ Reading the material

- $\quad$ Listening to the teacher in understanding the material

- Doing the task

- Material example with dialogue

- Material example with text/description

- Material presentation with colorful picture

Based on the results of the need inventory, many students like English lessons, such as reading, writing, listening, and speaking. However, some of them have not been able to understand the material properly due to several factors, both internal and external factors. In the learning abilities, students have been able to introduce themselves by using English, but not all can. Therefore, the researcher present the material about introducing. So that in the future, all students are able to introduce themselves.

Besides, introducing themselves in English can improve speaking skills, the researcher also wants to improve students' abilities in writing and reading because some of students do not yet have these abilities. Therefore, the researcher has presented many writing and reading activities related to daily life that are designed to be interesting so that students do not feel bored. In addition, the researcher also presents a lot of assignments for students, both individually, pairs, and in groups so that students' abilities can be further improved. Detailed information on the students' learning needs can be seen in the following table:

Table 2. The overall needs inventory from learning needs

\begin{tabular}{|c|c|c|}
\hline \multicolumn{3}{|c|}{ Learning needs } \\
\hline & The learning problems & The learning attitudes \\
\hline & & Learning preferences: \\
\hline & explanation & - Using an audio as the media in \\
\hline & Don't understand the explanation in the & learning process \\
\hline & book & - Using a picture as the media in \\
\hline & Don't understand the meaning of the & learning process \\
\hline & teacher's explanation & - $\quad$ Using a video as the media in learning \\
\hline & Don't understand the meaning of the text & process \\
\hline & & $\begin{array}{l}\text { - Asking for teacher in learning process } \\
\text { if students are in difficulties }\end{array}$ \\
\hline & & $\begin{array}{l}\text { - Asking for friend in learning process if } \\
\text { students are in difficulties }\end{array}$ \\
\hline & & $\begin{array}{l}\text { - Reading material repeatedly in } \\
\text { learning process if students are in } \\
\text { difficulties }\end{array}$ \\
\hline & & Learning styles: \\
\hline & & $\begin{array}{l}\text { - Listening to the teacher's explanation } \\
\text { in learning process }\end{array}$ \\
\hline
\end{tabular}


- Learning by game in learning process

- $\quad$ Learning by media/tools in learning process

- Working in group

- Working in pair

- Working alone

Students learning preference based on media was divided into three; using audio-based media, visual-based media, and audio-visual-based media in learning process. The visual-based media (image or parable) can be representational images (images, paintings, or photographs), diagrams (describing the relationships of concepts, organization, and structure of material content), maps (showing space relationships), graphs (tables, graphs, charts (charts) that present data / trend tendencies or between relationships of a set of images or numbers), audio-based media are media that contain messages in the form of auditive (only can be heard) that can stimulate thoughts, feelings, attention, and the ability of students to learn English instructional materials, and audiovisual based media is combining the use of sound with a pictorial display commonly called video (Azhar Arsyad:2007). The result showed if the three media are in the material. The visual media can be seen in each part of the material which displayed with full colorful picture and audio-visual media can be seen in each material example which displayed another students doing a role play as the speakers in each dialog.

In learning process, usually students get problem in understanding the material, to cover the problem students do three things; asking to the teacher, asking to friends, and reading material repeatedly. The appropriate of three things above can be seen in the material which displayed in each step of inquiry, where the material guides the students to do individual activities, work in pairs, and make a group discussion to do the activities. In individual activities, students can learn independently, whereas work in pairs and group discussion, the three things of the way students covered their problems were used. The students can ask their teacher, their friends or reading the material repeatedly.

In analyzing basic competencies, researcher created indicators of competencies achievement in each basic competency to facilitate researcher in designing materials according to indicators. There are 3 types of indicators that are created in analyzing a basic competency, here is the division. If the operational verb was in points 1 , the researcher made the main indicator and enrichment indicator, if the operational verb was in points $2,3,4$ or 5 the researcher made 
supporting indicators, main indicators, and enrichment indicators, and if the operational verb was in points 6 the researcher made supporting indicators and main indicators.

After gathering information that explained above, the researcher started to design the blueprint of the material as a material framework which details several aspects which would be made in the form of intact materials. There are five contents that should be included in the syllabus. The first is basic competency which displayed is basic competencies 3.1, 3.2, 4.1 and 4.2 then were explained each basic competency to the indicators that it has. The second is subject matter is the main reference that elaborated through material arranged in the form of material, activities, and exercise. Based on the description of the basic competency, the subject matter contains three main aspects, namely social function, text structure, and linguistic elements. The third is learning material is a set of material that compiled based on the results of basic competency analysis that produced new indicators and then new material. The fourth is indicator of competence achievement contained three types of indicators, namely, supporting indicator, main indicator, and enrichment indicator describing the subject matter. The fifth is learning activities consisted of two aspects, students' activities and teacher's activities that designed based on inquiry learning model which consisted of orientation, formulating problem, formulating hypothesis, collecting information, testing hypothesis, and conclusion.

After designing the blueprint, the materials' structure was developed by using inquiry learning model. The explanation of material representations on each step of the inquiry model which was a learning model used in arranging the materials' structure.

\section{The Result of Expert's Validation Towards the Materials' Contents}

Before implementing the developed English instructional materials in the classroom, it is essential that the English instructional materials be reviewed by the experts. The review was carried out to make sure that the English instructional materials have been well developed and ready to use according to the experts' statement.

Table 3. The result of the English materials and worksheets review of expert

\begin{tabular}{|c|c|c|c|}
\hline Statement & Score & Description & Follow up \\
\hline \multicolumn{4}{|l|}{ 1. Cover design } \\
\hline $\begin{array}{l}\text { 1.1 The cover is attractive to the } \\
\text { learners }\end{array}$ & 4 & $\begin{array}{c}\text { Very } \\
\text { appropriate }\end{array}$ & $\begin{array}{c}\text { No } \\
\text { revision } \\
\text { needed }\end{array}$ \\
\hline \multicolumn{4}{|l|}{ 2. Layout } \\
\hline 2.1 The layout is clear for learners & 4 & $\begin{array}{c}\text { Very } \\
\text { appropriate }\end{array}$ & $\begin{array}{c}\text { No } \\
\text { revision } \\
\text { needed }\end{array}$ \\
\hline
\end{tabular}


Volume 2, Number 1, March 2020

\begin{tabular}{|c|c|c|c|}
\hline $\begin{array}{l}2.2 \text { The layout is attractive to the } \\
\text { learners }\end{array}$ & 4 & $\begin{array}{c}\text { Very } \\
\text { appropriate }\end{array}$ & $\begin{array}{l}\text { No } \\
\text { revision } \\
\text { needed }\end{array}$ \\
\hline \multicolumn{4}{|l|}{ 3. Instructional objectives } \\
\hline 3.1 The instructional objectives are clear & 4 & $\begin{array}{c}\text { Very } \\
\text { appropriate }\end{array}$ & $\begin{array}{l}\text { No } \\
\text { revision } \\
\text { needed }\end{array}$ \\
\hline $\begin{array}{l}3.2 \text { The instructional objectives are } \\
\text { understandable }\end{array}$ & 4 & $\begin{array}{c}\text { Very } \\
\text { appropriate }\end{array}$ & $\begin{array}{c}\text { No } \\
\text { revision } \\
\text { needed }\end{array}$ \\
\hline $\begin{array}{l}3.3 \text { The instructional objectives ordered } \\
\text { appropriately }\end{array}$ & 4 & $\begin{array}{c}\text { Very } \\
\text { appropriate }\end{array}$ & $\begin{array}{l}\text { No } \\
\text { revision } \\
\text { needed }\end{array}$ \\
\hline $\begin{array}{l}3.4 \text { The instructional objectives reflect to } \\
\text { the topic }\end{array}$ & 4 & $\begin{array}{c}\text { Very } \\
\text { appropriate }\end{array}$ & $\begin{array}{l}\text { No } \\
\text { revision } \\
\text { needed }\end{array}$ \\
\hline 4. Organization of material & 4 & $\begin{array}{c}\text { Very } \\
\text { appropriate }\end{array}$ & $\begin{array}{l}\text { No } \\
\text { revision } \\
\text { needed }\end{array}$ \\
\hline $\begin{array}{l}4.1 \text { The materials are organized } \\
\text { attractively }\end{array}$ & 4 & $\begin{array}{c}\text { Very } \\
\text { appropriate }\end{array}$ & $\begin{array}{c}\text { No } \\
\text { revision } \\
\text { needed }\end{array}$ \\
\hline $\begin{array}{l}4.2 \text { The organization of material in the } \\
\text { form of units is appropriate }\end{array}$ & 4 & $\begin{array}{c}\text { Very } \\
\text { appropriate }\end{array}$ & $\begin{array}{l}\text { No } \\
\text { revision } \\
\text { needed }\end{array}$ \\
\hline $\begin{array}{l}4.3 \text { The materials are organized in } \\
\text { logically ordered tasks }\end{array}$ & 4 & $\begin{array}{c}\text { Very } \\
\text { appropriate }\end{array}$ & $\begin{array}{l}\text { No } \\
\text { revision } \\
\text { needed }\end{array}$ \\
\hline $\begin{array}{l}\text { 4.4 The themes and topics are relevant to } \\
\text { the learning material in each basic } \\
\text { competency. }\end{array}$ & 4 & $\begin{array}{c}\text { Very } \\
\text { appropriate }\end{array}$ & $\begin{array}{l}\text { No } \\
\text { revision } \\
\text { needed }\end{array}$ \\
\hline $\begin{array}{l}4.5 \text { They are arranged in a logical } \\
\text { sequence on the basis of topic or theme } \\
\text { following the indicators }\end{array}$ & 4 & $\begin{array}{c}\text { Very } \\
\text { appropriate }\end{array}$ & $\begin{array}{l}\text { No } \\
\text { revision } \\
\text { needed }\end{array}$ \\
\hline $\begin{array}{l}4.6 \text { The material cover a variety of topics } \\
\text { and situation following the indicators }\end{array}$ & 4 & $\begin{array}{c}\text { Very } \\
\text { appropriate }\end{array}$ & $\begin{array}{l}\text { No } \\
\text { revision } \\
\text { needed }\end{array}$ \\
\hline $\begin{array}{l}4.7 \text { The material have already represented } \\
\text { the indicators }\end{array}$ & 4 & $\begin{array}{c}\text { Very } \\
\text { appropriate }\end{array}$ & $\begin{array}{l}\text { No } \\
\text { revision } \\
\text { needed }\end{array}$ \\
\hline $\begin{array}{l}4.8 \text { The materials are organized in } \\
\text { logically ordered tasks following the } \\
\text { blueprint }\end{array}$ & 4 & $\begin{array}{c}\text { Very } \\
\text { appropriate }\end{array}$ & $\begin{array}{l}\text { No } \\
\text { revision } \\
\text { needed }\end{array}$ \\
\hline $\begin{array}{l}\text { 4.9 The material are appropriate with the } \\
\text { structure of inquiry learning model }\end{array}$ & 4 & $\begin{array}{c}\text { Very } \\
\text { appropriate }\end{array}$ & $\begin{array}{l}\text { No } \\
\text { revision } \\
\text { needed }\end{array}$ \\
\hline $\begin{array}{l}\text { 4.10 The material consist of the subject } \\
\text { matters }\end{array}$ & 4 & $\begin{array}{c}\text { Very } \\
\text { appropriate }\end{array}$ & $\begin{array}{l}\text { No } \\
\text { revision } \\
\text { needed }\end{array}$ \\
\hline $\begin{array}{l}4.11 \text { The material compiled based on the } \\
\text { cognitive domain has fulfilled the HOTS } \\
\text { level }\end{array}$ & 4 & $\begin{array}{c}\text { Very } \\
\text { appropriate }\end{array}$ & $\begin{array}{l}\text { No } \\
\text { revision } \\
\text { needed }\end{array}$ \\
\hline $\begin{array}{l}4.12 \text { The material compiled based on the } \\
\text { psychomotor domain has fulfilled the } \\
\text { HOTS level }\end{array}$ & 4 & $\begin{array}{c}\text { Very } \\
\text { appropriate }\end{array}$ & $\begin{array}{l}\text { No } \\
\text { revision } \\
\text { needed }\end{array}$ \\
\hline
\end{tabular}




\begin{tabular}{|c|c|c|c|}
\hline \multicolumn{4}{|l|}{ 5. Systematic Content of English } \\
\hline $\begin{array}{l}\text { 5.1 The integrated skills are appropriate to } \\
\text { the student level and needs. }\end{array}$ & 4 & $\begin{array}{c}\text { Very } \\
\text { appropriate }\end{array}$ & $\begin{array}{l}\text { No } \\
\text { revision } \\
\text { needed }\end{array}$ \\
\hline $\begin{array}{l}5.2 \text { There are three subject matters (social } \\
\text { function, structure text, and linguistics } \\
\text { element) in each basic competency. }\end{array}$ & 4 & $\begin{array}{c}\text { Very } \\
\text { appropriate }\end{array}$ & $\begin{array}{c}\text { No } \\
\text { revision } \\
\text { needed }\end{array}$ \\
\hline $\begin{array}{l}5.3 \text { The structure of arranging the } \\
\text { materials following the inquiry learning } \\
\text { model }\end{array}$ & 4 & $\begin{array}{c}\text { Very } \\
\text { appropriate }\end{array}$ & $\begin{array}{l}\text { No } \\
\text { revision } \\
\text { needed }\end{array}$ \\
\hline \multicolumn{4}{|l|}{ 6. Activities/ Exercises/ Tasks } \\
\hline $\begin{array}{l}6.1 \text { The activities, exercises and tasks are } \\
\text { interesting. }\end{array}$ & 4 & $\begin{array}{c}\text { Very } \\
\text { appropriate }\end{array}$ & $\begin{array}{l}\text { No } \\
\text { revision } \\
\text { needed }\end{array}$ \\
\hline $\begin{array}{l}6.2 \text { The activities, exercises and task are } \\
\text { aimed in developing student } \\
\text { comprehension. }\end{array}$ & 4 & $\begin{array}{c}\text { Very } \\
\text { appropriate }\end{array}$ & $\begin{array}{c}\text { No } \\
\text { revision } \\
\text { needed }\end{array}$ \\
\hline $\begin{array}{l}6.3 \text { They provide for a real world use of } \\
\text { language in daily lives. }\end{array}$ & 4 & $\begin{array}{c}\text { Very } \\
\text { appropriate }\end{array}$ & $\begin{array}{l}\text { No } \\
\text { revision } \\
\text { needed }\end{array}$ \\
\hline $\begin{array}{l}6.4 \text { The situations of the activities, } \\
\text { exercises and tasks in each subject matter } \\
\text { are appropriate to the learner's level and } \\
\text { need. }\end{array}$ & 4 & $\begin{array}{c}\text { Very } \\
\text { appropriate }\end{array}$ & $\begin{array}{l}\text { No } \\
\text { revision } \\
\text { needed }\end{array}$ \\
\hline $\begin{array}{l}6.5 \text { The activities, exercises and tasks } \\
\text { provide for varying learning arrangement } \\
\text { like pairs and working in group. }\end{array}$ & 4 & $\begin{array}{c}\text { Very } \\
\text { appropriate }\end{array}$ & $\begin{array}{c}\text { No } \\
\text { revision } \\
\text { needed }\end{array}$ \\
\hline $\begin{array}{l}\text { 6.6 The activities, exercises and tasks } \\
\text { focus on student's comprehension for } \\
\text { each indicator. }\end{array}$ & 4 & $\begin{array}{c}\text { Very } \\
\text { appropriate }\end{array}$ & $\begin{array}{c}\text { No } \\
\text { revision } \\
\text { needed }\end{array}$ \\
\hline $\begin{array}{l}\text { 6.7 The instruction for the activities, } \\
\text { exercises and tasks are simple and clear. }\end{array}$ & 4 & $\begin{array}{c}\text { Very } \\
\text { appropriate }\end{array}$ & $\begin{array}{l}\text { No } \\
\text { revision } \\
\text { needed }\end{array}$ \\
\hline $\begin{array}{l}6.8 \text { The activities, exercises and tasks } \\
\text { allow for the teacher's initiative to modify } \\
\text { the activities. }\end{array}$ & 4 & $\begin{array}{c}\text { Very } \\
\text { appropriate }\end{array}$ & $\begin{array}{l}\text { No } \\
\text { revision } \\
\text { needed }\end{array}$ \\
\hline $\begin{array}{l}\text { 6.9 The activities, exercises and tasks' } \\
\text { instruction are clear and structured }\end{array}$ & 4 & $\begin{array}{c}\text { Very } \\
\text { appropriate }\end{array}$ & $\begin{array}{c}\text { No } \\
\text { revision } \\
\text { needed }\end{array}$ \\
\hline $\begin{array}{l}\text { 6.10 The activities have presented the } \\
\text { HOTS criteria of the cognitive level }\end{array}$ & 4 & $\begin{array}{c}\text { Very } \\
\text { appropriate }\end{array}$ & $\begin{array}{l}\text { No } \\
\text { revision } \\
\text { needed }\end{array}$ \\
\hline $\begin{array}{l}\text { 6.11 The activities have presented the } \\
\text { HOTS criteria of the psychomotor level }\end{array}$ & 4 & $\begin{array}{c}\text { Very } \\
\text { appropriate }\end{array}$ & $\begin{array}{c}\text { No } \\
\text { revision } \\
\text { needed }\end{array}$ \\
\hline
\end{tabular}

Source: Adapted from Ghobrani (2011: 517-518) and Wodyatmoko (2011) cited Sukirman (2013)

The results of the evaluation were quoted from the observation sheets that have been given to the experts. The observation sheet consisted at several items such as cover, layout, instructional objective, organization of materials, the systematic content of the materials, and activities/tasks/exercise are already checked with a good mark. After all the items marked and resulted good, the learning materials then claimed valid as reflected to the experts suggestions: 
The English instructional materials have been very well designed due to the followed reasons: (the first expert) The objectives and goals were stated, it has development framework, and it systematically present the idea of based on inquiry learning model supported with the HOTS indicators. (The second expert) overall the material and the content are appropriate with the blueprint. In conclusion, the validity level of the material development are very appropriate to the blueprint due to the validation checklist.

\section{CONCLUSION}

The conclusion of this research is English materials development in the seventh grade of MTs Madani Pao-pao based on the Blueprint consist of 144 indicators which displayed in 42 phases in the material includes conceptual map, goals, materials sequence, and product overview. Besides, it was also found that the expert validation for the development of product such as English materials and worksheet has been very well designed.

\section{REFERENCES}

"ADDIE Model". Instructional Systems, College of Education, Penn State, University.http://www.instructionaldesigncentral.com/htm/IDC_instruction aldesignmodels.htm\#Addie. (May 2015).

Adilah, Naila. (2013). Analysis of curriculum 2013 implemented at seven grade of smp 2 bandarlampung. Journal (Online).

Ahmad, Djuwairiah and Hikmawati. "Developing Greetings and Self Introducing Materials Dealing with 2013 Curriculum of The Seventh Grade in MTs Balang-balang." Thesis. Makassar: School of Graduate Studies, State Islamic University of Alauddin. 2016.

Akker, Jan van den. 1999. Design Approaches and Tools in Education and Training. The Netherlands, University of Twente.

Aldoobie, Nada. (2015). ADDIE Model. University Of Northern Colorado. American International Journal of Contemporary Research Vol. 5, No. 6; December 2015.

Amalia, Mila. (2016). Meningkatkan Aktivitas dan Hasil Belajar Siswa dengan Model Inquiry Based Learning Tipe Make a Match dalam Mata Pelajaran Pendidikan Kewarganegaraan. Thesis.

Arikunto, Suharsimi. Prosedur Penelitian. Jakarta: Rineka Cipta. 2013.

Barrow, Lloyd H. (2006). A Brief History of Inquiry: From Dewey to Standards. Journal of Science Teacher Education 17:265-278. 
Donough, Mc\&Masuhara H. (2013). Materials and Methods in ELT: A Teacher's Guide (3 Ed.). London: John Wiley \& Sons, Inc.

Dudley-Evans \& John ST. 1998. Developments in English for Specific Purposes, Cambridge: Cambridge University Press.

Ghozali, I. 2011. Pengembangan Buku Teks Bahasa Inggris Integratif untuk Sekolah Menengah Kejuruan: Penelitian Pengembangan Pendidikan di Sekolah Menengah Kejuruan Usaha Jasa Pariwisata di Yogyakarta. Thesis. Universitas Sebelas Maret Semarang.

Gormally, Cara, Peggy Brickman, Brittan Hallar, and Norris Armstrong. Effects of Inquiry Learning on Students' Science Literacy Skills and Confidence. International Journal for the Scholarship of Teaching and Learning: Vol. 3: No. 2, Article 16.University of Georgia. 2009.

Grath, I. Mc. (2002). Materials Evaluation and Design for Language Teaching. Edinburgh: Edinburgh University Press.

Gustafson Kent. L \& Branch Maribe. R. 2002. Survey of Instructional Development Models, New York: Syracuse University.

Handoyono, Nurcholish A. and Zainal A. (2016). Pengaruh Inquiry Learning dan Problem-Based Learning Terhadap Hasil Belajar PKKR Ditinjaudari Motivasi Belajar. Jurnal Pendidikan $6(1), 31-42$.

Harsono, Y.M. 2007.Developing Learning Material for Specific Purposes. Thesis. Universitas Katlik Atma Jaya, Jakarta.

Haryati, M. 2008. Model dan Teknik Penilaian pada Tingkat Satuan Pendidikan. Jakarta: Gaung Persada Press. Hlm. 1.

Hills, Ruth. 2000. Developing Instructional Material in the Sloan Experiment, University of Kentucky, Washington.

Hutchinson, T \& Waters, A. 1998.English for Specific Purposes: A Learning Centered Approach, Cambridge University Press, Cambridge.

Ilmiah, Nur and Nur Aliyah Nur. (2018). Developing Asking and Giving Information Materials Dealing with 2013 Curriculum of SMP Eight Grade.Eternal (English, teaching, learning, and research journal), 4(1), 67-78.

Joyce, B. R., Marsha Weil, and Emily Calhoun.(2015). Models of Teaching, 9th Edition. https://www.pearson.com/us/higher-education/program/Joyce-Models-of-Teaching-9thEdition/PGM243928.html?tab=authors. (18 November 2018). 
Volume 2, Number 1, March 2020

Kemendikbud. 2014. Modul Pelatihan Implementasi Kurikulum 2013. Jakarta: Badan Pengembangan Sumber Daya Manusia dan Kebudayaan.

Khoir, Miftahul. 2015. Developing English Learning Materials for Young Learners Based on Needs Analysis. Thesis. Makassar: School of Graduate Studies, State Islamic University of Alauddin.

Kusmaryono, Heru and RokhisSetiawati. (2013). Penerapan Inquiry Based Learning untuk Mengetahui Respon Belajar Siswa pada Materi Konsep dan Pengelolaan Koperasi. Jurnal Pendidikan Ekonomi Dinamika Pendidikan.

Latief, A. (2013). Research Methods on Language Learning: An Introduction. Universitas Negeri Malang Press, Malang.

McGriff. Steven J. (2000). Instructional System Design (ISD): Using the ADDIE Model. Instructional Systems, College of Education, Penn State University.

Miles, MB. \& Huberman, AM. (1994). Qualitative Data Analysis (2nd edition). Thousand Oaks, CA: Sage Publications.

Mubarak, Husni. "Material Development for Basic Competenceies 3.7 and 4.7 of The 2013 English Syllabus for The Eighth Grade at Junior High School 02 Sungguminasa, Gowa." Thesis. Makassar: School of Graduate Studies, State Islamic University of Alauddin. 2017.

Mulyasa, E. (2013). Pengembangan dan Implementasi Kurikulum 2013. Bandung: Rosdakarya, p. 163.

Ontario. (2013). Inquiry-based Learning. Capacity Building Series. ISSN: 1913849.

Pedoman Pelatihan Implementasi Kurikulum 2013, Kementarian Pendidkan dan Kebudayaan Tahun 2013, p. 4.

Pratt, B.1980. Curriculum Design and Development. New York: Harcourt Brace Javanovich Publishers. Pg. 4.

Richard, Jack C. Curriculum Development in Language Teaching. New York: Cambridge University Press. 2007.

Safrizal. (2013). Designing ESP English instructional material for Students of Accounting Department of Al-Azhar University Medan. Thesis.Al-Azhar University Medan.

Sani, Ridwan Abdullah. (2010). The Characteristics of Inquiry-Based Learning.https://www.academia.edu/19895920/Buku_Pembelajaran_Saintifik. November 2018). 
Seels B \& Glasgow Z.(1998).Making Instructional Design Decisious 2nd edition. Upper Saddle River, NJ: Merrill, Prentice-Hall.

Sujadi, Imam and Suardi. (2017). Desain Pembelajaran. Taken from https://ml.scribd.com/document/357888455/BAB-4-DESAIN PEMBELAJARAN-pdf. Paper presented in the PLPG program.

Sunardi and Imam Sujadi. (2017). Desain Pembelajaran. Sumber Belajar Calon Peserta Program PLPG.

Sundari, Tantri. (2014). An Analysis on K-13 of Seventh Grade Students "When English Rings the Bell” PAPER Submitted to fulfill the requirements of Principle of Language Teaching Midterm \& Final Exam.

Suyadi. 2016. English for Specific Purposes for Accounting Students. IJIRES, vol. 3, no. 1, hh.144.

Tomlinson, B.(1998). Material Development in Language Teaching. Cambridge: Cambridge University Press.

Triandy, Rendy. (2017). Pembelajaran Mengidentifikasi Ide Pokok dalam Artikel dengan Metode Inquiry pada Siswa Kelas X SMA Pasundan 2 Bandung. LITERASI, Jurnal Ilmiah Pend. Bahasa, Sastra Indonesia dan Daerah.

Undang-Undang Nomor 20 Tahun 2003 tentang Sistem Pendidikan Nasional, Lembaran Negara Republik Indonesia Tahun 2003 Nomor 78.

Youth Learn. (2016). Inquiry-Based Learning: An Approach to Educating and Inspiring Kids. 